удК 343.9:(343.359+343.37)

\title{
I. B. Маслій
}

\section{ДО ПИТАННЯ ПРО ВИЗНАЧЕННЯ ПОНЯТТЯ ТА СТРУКТУРИ ЗЛОЧИННОСТі У ФіНАНСОВО-ЕКОНОМ ІЧНІЙ СФЕРі ЯК ЕЛЕМЕНТ ÏÏ КРИМІНОЛОГІЧНОЇ ХАРАКТЕРИСТИКИ}

Злочинність у фінансово-економічній сфері супроводжує трансформаційні процеси в економіці України. Кількість вчинених злочинів, їх склад зазнає змін відповідно до міри і ступеня наявності кризових явищ у економіці, керованості з боку держави процесами розвитку економіки, становлення і функціонування фінансової системи.

Ці загальні положення підтверджує статистика правоохоронної діяльності органів внутрішніх справ. Однак при аналізі кількісних показників слід враховувати зміни у структурі економічної злочинності у зв'язку із набуттям чинності у 2001 році Кримінальним кодексом України [1]. За Кримінальним кодексом України від 28.12.1960 року [2] станом на 1997 рік злочинами економічної спрямованості визнавались злочини проти соціалістичної власності, злочини проти особистої власності громадян, господарські злочини. Відповідно до Кримінального кодексу України від 05.04.2001 року станом на 2003 рік до злочинів економічної спрямованості були віднесені: злочини проти власності, злочини у сфері господарської діяльності. До складу злочинів у сфері господарської діяльності було включено легалізацію (відмивання) грошових коштів та іншого майна, здобутих злочинним шляхом (ст. 209 КК України), а також ухилення від сплати податків, зборів, інших обов'язкових платежів (ст. 212 КК України).

Враховуючи зміну структури статистичних показників обліку злочинності, певні висновки можна отримати, якщо порівнювати не абсолютні, а відносні показники, зокрема - показник питомої ваги злочинів у банківській сфері у загальній структурі злочинів економічної спрямованості.

Так, «пік» злочинів у банківській сфері прийшовся на 1999 рік. На той час спостерігалось слабке управління ризиками та низка 
стабільність банківської системи, невміле управління державою своєю власністю у державних банках (Ощадбанку). Банкнотна фабрика Національного банку України була завантажена на 20-30 відсотків [3]. Станом на 01.01.2013 року в Україні діяло 176 банків (в т.числі - 1санаційний «Родовід Банк»). Протягом 2012 року приріст чистих активів банківської системи України складав 15,9 \%, або 168,7 млрд грн, головним чином за рахунок припливу клієнтських коштів (15\%) [4].

Достатньо стабільна та жорстко контрольована банківська сфера вплинула на динаміку злочинності у банківській та фінансово-економічній сфері. Так, за даними МВС України у 2011 та 2012 роках питома вага злочинів у банківській сфері у загальній кількості злочинів економічної спрямованості майже у 60 разів менша, ніж злочинів у фінансово-економічній сфері.

Здійснюючи кримінологічну характеристику злочинів у сфері економіки в Україні, вчені виділяли їх поширеність, яка проявляється у тому, що вони займають найбільшу частку в структурі усієї зареєстрованої злочинності (майже $10 \%$ злочинів, що висвітлюються у статистиці як діяння у сфері економіки, та 40 \% посягань економічної спрямованості, які відбиваються в інших статистичних групах). У зв'язку з цим збитки від таких злочинів сягають понад 5 млрд грн [5, с. 127]. Таку ж саме ознаку щодо злочинності у сфері економічної діяльності відносно загального числа зареєстрованих злочинів економічного характеру в Російській Федерації відзначають В. Д. Пахомов, Ю. М. Демідов, А. І̇. Долгова [6, с. 694].

Сучасні наукові дослідження, а також аналітичні матеріали, підготовлені за результатами узагальнення правозастосовної діяльності правоохоронних органів, містять різні змістовні характеристики поняття економічної злочинності, у цьому понятті відсутні чіткі кримінально-правові межі, також використовуються як синонімічні такі поняття, як «економічна злочинність», «злочинність у сфері господарської діяльності», «злочинність у сфері економіки».

Економічну злочинність у кримінологічному аспекті на рівні докторських дисертацій в Україні досліджували О. Г. Кальман [7], А. М. Бойко [8]. Кримінологічну характеристику економічної злочинності надано у підручниках та навчальних посібниках з кримінології, підготовлених вченими як в Україні, так і в Росії (В. В.Лунєєв [9], О. М. Джужа, М. Ю. Валуйська [5], В. В. Василевич, В. В. Голіна, І̇. М. Даньшин, А. І̇. Долгова [6], А. П. Закалюк [10; 11], В. М. Попович [12] та інші.

На думку В. В. Лунєєва, економічні злочини - істотна частина корисливої злочинності, яка безпосередньо пов'язана із економічними відносинами. Вчений підкреслює, що кримінологічне розуміння цієї групи діянь у взаємозв'язку із кримінальним правом ще більш не визначено, ніж сама корислива злочинність. Проте економічні злочини виділяються у самостійну групу, оскільки для цього $є$ усі підстави - економічні, соціальні, кримінологічні і навіть - політичні [9, с. 430]. Критично аналізуючи за- 
пропонований підхід, В.В.Лунєєв визначає сутність економічної злочинності у країнах із ринковою економікою - iі складають злочини, які вчиняються корпораціями проти державної економіки, проти інших корпорацій, службовцями корпорацій проти самої корпорації, корпораціями проти споживачів. Проте вчений зазначає відсутність кримінальної відповідальності юридичних осіб у інших країнах [9, с. 432]. Характеризуючи економічну злочинність, В. В. Лунєєв вказував, насамперед, про ії латентний характер, корисливі мотиви вчинення, «зрощення» 3 організованою злочинністю [9, с. 437-438].

Отже, логічним висновком, виходячи з підходу В. В. Лунєєва щодо сутності економічної злочинності, може бути висновок про необхідність запровадження кримінальної відповідальності юридичних осіб. Такий підхід навіть самим вченим визначається неоднозначно.

Визнання взаємозв'язку економічної та організованої злочинності, наявності такої ознаки, як спрямованість внаслідок вчинення такого виду злочину на підрив економічних інтересів держави визначає доцільність включення до кола злочинів у фінансово-економічній сфері порушення авторського права і суміжних прав (ст. 176 КК України), порушення прав на винахід, корисну модель, промисловий зразок, топографію інтегральної мікросхеми, сорт рослин, раціоналізаторську пропозицію (ст. 177 КК України), використання коштів, здобутих від незаконного обігу наркотичних засобів, психотропних речовин, їх аналогів, прекурсорів, отруйних чи сильнодіючих речовин або отруйних чи сильнодіючих лікарських засобів (ст. 306 КK України).

Включення злочину, кримінальна відповідальність за вчинення якого передбачена ст. 176 КК України, до складу злочинів у сфері фінансовоекономічної діяльності грунтується на зв'язку цього злочину із завданням матеріальної шкоди у значному розмірі та наявністю причино-наслідкового зв'язку між суспільно небезпечними діями та завданням матеріальної шкоди внаслідок їх вчинення.

Наявність причинно-наслідкового зв'язку між вчиненими діями щодо порушення прав на винахід, корисну модель, промисловий зразок, топографію інтегральної мікросхеми, сорт рослин, раціоналізаторську пропозицію та завданою матеріальною шкодою $є$ основною і обов'язковою ознакою об’єктивної сторони злочину за ст. 177 КК України, що прямо випливає з диспозицій ч. 1, 2 цієї статті.

Предмет злочину за ст. 306 КК України стосується коштів, отриманих від незаконного обігу наркотичних засобів, психотропних речовин, їх аналогів і прекурсорів і які використовуються 3 метою їх відмивання. Відмивання грошей - це злочинна діяльність, переважно у міжнародному масштабі, яка характеризується умисним укриттям дійсного походження (джерела) майна або фінансових засобів шляхом незаконного їх використання з метою «легалізації» злочинних доходів. Об'єктивна сторона злочину передбачає три альтернативних дії: 1) розміщення коштів у банках, на підприємствах, установах, організаціях, їх підрозділах; 2) придбання за 
ці кошти об’єктів, майна, які підлягають приватизації, або обладнання для виробничих чи інших потреб; 3) використання таких засобів та майна 3 метою продовження незаконного обігу наркотичних засобів, психотропних речовин, їх аналогів і прекурсорів [13, с. 835-836].

Отже, доцільність включення злочину, пов'язаного із використанням коштів, здобутих від незаконного обігу наркотичних засобів, психотропних речовин, їх аналогів, прекурсорів, отруйних чи сильнодіючих речовин або отруйних чи сильнодіючих лікарських засобів (ст. 306 КК України), до кола злочинів у фінансово-економічній сфері обумовлена метою вчинення - «легалізація» коштів, отриманих злочинним шляхом, об'єктивною стороною діяння, пов'язаного із здійсненням дій з використанням банківської системи, вкладанням та використанням коштів у сфері економіки.

Завдання матеріальної шкоди може бути обов'язковою ознакою не тільки перелічених видів злочинів, якими пропонується доповнити коло злочинів у фінансово-економічній сфері. Їх включення грунтується, у першу чергу, на тому, що внаслідок їх вчинення завдається шкода економічним інтересам держави, оскільки питання дотримання права інтелектуальної власності є загальнодержавним завданням, вирішення якого впливає на економічний розвиток держави. Такий вплив має діяльність щодо запобігання і протидії легалізації (відмиванню) доходів, одержаних злочинним шляхом.

Російські вчені - В. Д. Пахомов, Ю. М. Демідов, А. І̇. Долгова формулюють докладне визначення поняття економічної злочинності. Такою визначено сукупність протиправних, суспільно небезпечних, корисливих, таких, що спричиняють істотну матеріальну шкоду внаслідок посягань на встановлений порядок управління економічними процесами та економічні права та інтереси громадян, юридичних осіб і держави 3 боку осіб, які виконують певні функції у системі економічних відносин [6, с. 692].

Не заперечуючи жодним чином проти викладеного підходу, тим не менше, не зайвим буде зазначити, що його використання дозволяє віднести до економічної злочинності дрібні крадіжки, шахрайства, адже істотність матеріальної шкоди - категорія відносна, а іiі формальне визначення здійснене тільки для конкретних видів злочинів. Крім того, категорія «економічні права та інтереси» потребує додаткового обгрунтування. Більш обгрунтованим і більш зрозумілим є використання категорії «економічний розвиток держави, регіону», «стан фінансової безпеки», що дозволить підкреслити ступінь небезпеки вчиненого злочину. Саме посягання на стан фінансової безпеки в державі можна виділити як ознаку об’єкта легалізації (відмивання) доходів, одержаних злочинним шляхом, ухилення від сплати податків тощо.

На думку В. М. Поповича, економічні злочини — це діяння (дії чи бездіяльність), вчинені з завуальованим протиправним використанням легітимних технологічно-облікових операцій, фінансово-правових інстру- 
ментів, організаційно-регулятивних та контрольно-управлінських прав і повноважень, які з корисливих чи інших протиправних мотивів (підрив репутації, розголошення комерційної таємниці тощо) посягають на відносини, що охороняються кримінальним законом, пов“язані з фінансово-господарськими, господарсько-регулятивними, технологічно-обліковими і цивільно-правовими операціями щодо цивільного обороту коштів, речей, прав, дій [14, с. 402-405].

Однак таке визначення охоплює широке коло суспільних відносин, які охороняються кримінальним законом і у межах яких можуть вчинятись не тільки економічні, а й загальнокримінальні злочини. Саме тому воно вдається загальним і таким, яке не дозволяє врахувати специфіку економічної злочинності.

Визначаючи коло злочинів у фінансово-економічній сфері, слід вказати про науковий підхід, сформульований Іे. М. Даньшиним, про який вказує О. Г. Кальман, щодо основного критерію віднесення конкретного злочину до економічного. Таким названо спрямованість діяння проти економічної системи суспільства (об’єкт) і його наслідки (заподіяння істотної матеріальної шкоди об’єкту) [15, с. 237]. О. Г. Кальман обгрунтовує таке визначення злочинності у сфері економіки як соціально-економічне деструктивне для економіки держави явище, яке проявляється у вчиненні особами навмисних корисливих злочинів у сфері легальної і нелегальної економічної діяльності, основним безпосереднім об'єктом яких виступають відносини власності і відносини у сфері виробництва, обміну, розподілу і споживання товарів і послуг з метою отримання доходу [7, с. 50].

Не заперечуючи в цілому проти запропонованого О. Г. Кальманом визначення поняття злочинності у сфері економіки, тим не менше, можна зазначити про використання у ньому термінів, що потребують додаткового тлумачення, як-от: «легальна і нелегальна економічна діяльність». Ці терміни прийнятні для дослідження кримінологічного аспекту злочинності у сфері економіки, однак чинне законодавство не надає визначення «економічна діяльність». Разом з тим на підтримку заслуговує врахування основного безпосереднього об'єкта злочинів у сфері економіки, що не дозволяє застосувати широке значення таких злочинів, тим самим необмежено розширюючи межі їх кримінально-правової і кримінологічної характеристики.

Перспективною з точки зору врахування при формулюванні поняття злочинності у фінансово-економічній сфері вдається думка А. М. Бойка про те, що злочинність — це складова соціальної реальності, яка становить порівняно стійку, історично мінливу, якісно та змістовно неоднорідну сукупність суспільно небезпечних проявів соціальної активності певних членів суспільства, породжену закономірностями розвитку цього суспільства. Вчений підкреслює притаманність економічній злочинності ознак, характерних для поняття злочинності, за винятком тих, які визначають їі видову сутність. Тому, зазначає А. М. Бойко, формулюючи 
поняття економічної злочинності, передусім необхідно враховувати те, що йдеться про суспільно небезпечні прояви соціальної активності у сфері господарського життя суспільства, тобто про протиправну, суспільно небезпечну господарську діяльність деяких членів суспільства - суб’єктів такої діяльності [8, с. 79-80].

А. М. Бойко пропонує таке визначення економічної злочинності. Економічну злочинність можна вважати видом злочинності, яка становить спричинену закономірностями розвитку суспільства кримінологічно однорідну сукупність суспільно небезпечних і кримінально караних проявів господарської діяльності, які посягають на механізм організації національної економіки і вчиняються, як правило, суб'єктами господарської діяльності - фізичними особами, або службовими особами юридичних осіб - суб'єктів господарської діяльності у процесі здійснення ними фактичної чи фіктивної господарської діяльності через порушення порядку іiі здійснення з метою отримання економічної вигоди. Тобто до економічних злочинів належать діяння, які посягають на механізм організації національної економіки у процесі господарської діяльності й спрямовані на отримання економічної вигоди через порушення порядку здійснення господарської діяльності [8, с. 79-80].

Важливими і перспективними положеннями, обгрунтованими А. М. Бойком, є закріплення у запропонованому визначенні економічної злочинності таких ознак, як однорідна сукупність певних проявів, їх кримінальна караність, суспільна небезпечність. Проте таке визначення не дозволяє віднести до економічних злочинів злочини проти власності, хоча загальновідомо, що власність є основою економіки.

Враховуючи надбання вчених у напрямку визначення поняття злочинності у сфері економіки, економічної злочинності, а також необхідність включення до цього поняття і злочинів у фінансовій сфері, можна сформулювати таке поняття злочину у фінансово-економічній сфері.

Тож поняття злочинності у фінансово-економічній сфері можна сформулювати як сукупність однорідних протиправних, суспільно небезпечних, корисливих, таких, що спричиняють істотну матеріальну шкоду внаслідок посягань на встановлений порядок управління економічними процесами, економічний розвиток держави, стан фінансової безпеки діянь, за які передбачено кримінальну відповідальність.

Враховуючи таке визначення поняття злочинності у фінансово-економічній сфері, до таких злочинів можна віднести: а) злочини проти власності (розділ VI KK України); б) злочини у сфері господарської діяльності (розділ VII КK України); в) інші злочини економічного характеру (порушення авторського права і суміжних прав (ст. 176 KК України), порушення прав на винахід, корисну модель, промисловий зразок, топографію інтегральної мікросхеми, сорт рослин, раціоналізаторську пропозицію (ст. 177 КК України), використання коштів, здобутих від незаконного обігу наркотичних засобів, психотропних речовин, їх аналогів, прекурсорів, отруйних чи сильнодіючих речовин або отруйних чи 
сильнодіючих лікарських засобів (ст. 306 КК України)). При цьому у межах групи злочинів у сфері господарської діяльності, а також злочинів економічного характеру можна запропонувати виділити економічні злочини та фінансові злочини. До економічних злочинів віднести усі злочини економічного характеру та частину злочинів у сфері господарської діяльності. До групи фінансових злочинів - ті, склади яких передбачені статтями 200 «Незаконні дії з документами на переказ, платіжними картками та іншими засобами доступу до банківських рахунків, електронними грошима, обладнанням для їх виготовлення», 209 «Легалізація (відмивання) доходів, одержаних злочинним шляхом», 209-1 «Умисне порушення вимог законодавства про запобігання та протидію легалізації (відмиванню) доходів, одержаних злочинним шляхом, або фінансування тероризму», 210 «Нецільове використання бюджетних коштів, здійснення видатків бюджету чи надання кредитів з бюджету без встановлених бюджетних призначень або з їх перевищенням», 211 «Видання нормативно-правових актів, що зменшують надходження бюджету або збільшують витрати бюджету всупереч закону», 212 «Ухилення від сплати податків, зборів (обов'язкових платежів)», 212-1 «Ухилення від сплати єдиного внеску на загальнообов'язкове державне соціальне страхування та страхових внесків на загальнообов'язкове державне пенсійне страхування», 222 «Шахрайство 3 фінансовими ресурсами», 222-1 «Маніпулювання на фондовому ринку», 223-1 «Підроблення документів, які подаються для реєстрації випуску цінних паперів», 223-2 «Порушення порядку ведення реєстру власників іменних цінних паперів», 224 «Виготовлення, збут та використання підроблених недержавних цінних паперів», 231 «Незаконне збирання з метою використання або використання відомостей, що становлять комерційну або банківську таємницю», 232 «Розголошення комерційної або банківської таємниці», 232-1 «Незаконне використання інсайдерської інформації», 232-2 «Приховування інформації про діяльність емітента».

\section{Л і те р а т у р а}

1. Кримінальний кодекс України : Закон України від 5 квіт. 2001 р., № 2341-III // Відомості Верховної Ради України. - 2001. - № 25-26. - Ст. 131.

2. Кримінальний кодекс Української РСР : введено в дію Законом Української Радянської Соціалістичної Республіки від 28 груд. 1960 р. // Відомості Верховної Ради УРСР. - 1961. - № 2. - Ст. 14.

3. Парламентські слухання «Фінанси і банківська діяльність: сучасний стан та перспективи розвитку». 2 квітня 2003 року [Електронний ресурс]. - Режим доступу: http://www.gua.convdocs.org/docs/1222/index-54220.html.

4. Банківська система України у 2012 р.: стан і тенденції розвитку / IBI Rating/ Rating agency [Електронний ресурс]. - Режим доступу: www.ibi.com.ua/...) Review_Banki_Y2012_ukr.

5. Кримінологія. Загальна та Особлива частини : підручник / I. М. Даньщин, В. В. Голіна, М. Ю. Валуйська [та ін.] ; за ред. В. В. Голіни. - 2-ге вид., переробл. і допов. Х. : Право, 2009. - 288 с. 
6. Криминология : учебник / под. общ. ред. А. И. Долговой. - 4-е изд., перераб. и доп. - M. : Норма: Информа-M, 2010. - 1008 с.

7. Кальман О. Г. Злочинність у сфері економіки України: теоретичні та прикладні проблеми попередження : дис. ... д-ра юрид. наук : 12.00.08 / Кальман Олександр Григорович; Нац. юрид. акад. України ім. Ярослава Мудрого. - Х., 2004. - 431 с.

8. Бойко А. М. Теорія детермінації економічної злочинності в Україні в умовах переходу до ринкової економіки : дис. ... д-ра юрид. наук : 12.00 .08 / Бойко Андрій Михайлович; Львів. нац. ун-т ім. Ївана Франка. - Л., 2009. - 492 с.

9. Лунеев В. В. Курс мировой и российской криминологии: учебник. В 2 т. Т. 2. Особенная часть / В. В. Лунеев. - М. : Юрайт, 2011. - 872 с.

10. Закалюк А. П. Курс сучасної української кримінології: теорія і практика. У 3 кн. Кн. 1. Теоретичні засади та історія української кримінологічної науки / А. П. Закалюк. - К. : Вид. дім «Ін Юре»,2007. - 424 с.

11. Закалюк А. П. Курс сучасної української кримінології: теорія і практика. У 3 кн. Кн. 2. Кримінологічна характеристика та запобігання вчиненню окремих видів злочинів / А. П. Закалюк. - К. : Вид. дім «Ін Юре»,2007. - 712 с.

12. Попович В. М. Економіко-кримінологічна теорія детінізації економіки : автореф. дис. ... д-ра юрид. наук : 12.00 .08 / Попович Володимир Михайлович; Нац. акад. внутр. справ. - K., 2002. - 38 с.

13. Научно-практический комментарий Уголовного кодекса Украины от 5 апреля 2001 года / под ред. Н. И. Мельника, Н. И. Хавронюка. - К. : А.С.К., 2004. - 1216 с.

14. Попович В. М. Тіньова економіка як предмет економічної кримінології: монографія / В. М. Попович. - K. : Правові джерела, 1998. - 447 с.

15. Даньшин И. Н. Преступность в сфере экономики: некоторые уголовно-правовые и криминологические вопросы / И. Н. Даньщин // Актуальные проблемы формирования правового государства. - Х., 1990. - С. 237-240.

\section{А н о т а ц і я}

Macлiй $\dot{I} . B$. До питання про визначення поняття та структури злочинності у фінансово-економічній сфері як елемент її кримінологічної характеристики. Стаття.

У статті обгрунтовано поняття злочинності у фінансово-економічній сфері та запропоновано структуру системи злочинів, які доцільно віднести до злочинів у фінансовоекономічній сфері. Доведено, що злочинність у фінансово-економічній сфері являє собою сукупність однорідних протиправних, суспільно небезпечних, корисливих, таких, що спричиняють істотну матеріальну шкоду внаслідок посягань на встановлений порядок управління економічними процесами, економічний розвиток держави, стан фінансової безпеки діянь, за які передбачено кримінальну відповідальність. Запропоновано віднести до таких злочинів: злочини проти власності; злочини у сфері господарської діяльності; інші злочини економічного характеру.

Ключові слова: злочинність, фінансово-економічна сфера, кримінологічна характеристика

\section{А н нота ция}

Маслий И.В. К вопросу об определении понятия и структуры преступности в финансово-экономической сфере как элемент ё̈ криминологической характеристики. - Статья.

В статье обосновано понятие преступности в финасово-экономической сфере и предложена структура системы преступлений, которые целесообразно отнести к преступлениям в фінансово-экономической сфере. Доказано, что преступность в фінансово-эконо- 
мической сфере представляет совокупность однородных противоправных, общественно опасных, корыстных, таких, которые причиняют существенный материальный вред вследствие посягательств на установленный порядок управления экономическими процесами, экономическое развитие государства, состояние финансовой безопасности деяний, за которые предусмотрена уголовная ответственность. Предложено отнести к таким преступлениям: преступления против собственности; преступления в сфере хозяйственной деятельности; иные престепления экономического характера.

Ключевые слова: преступность, финансово-экономическая сфера, криминологическая характеристика

\section{S u m m a r y}

Masliy I. V. On the question of the concept and structure of crime in financial and economic sphere determining as an element of its criminological characteristics. - Article.

The concept of crime in financial and economic sphere is grounded and the structure of system of crimes, which should be attributed to the crimes in financial and economic sphere is proposed in the article. There proved that the crime in financial and economic sphere represents a set of acts which are: homogeneous illegal, socially dangerous, selfish, such that cause substantial material damage as a result of infringements of the established order of management of economic processes, economic development of the state, the financial security, for which criminal responsibility is contemplated. There proposed to attribute to such crimes: crimes against property, crimes in sphere of economic activity; other crimes of an economic nature.

Keywords: crime, financial and economic sphere, criminological characteristics. 